\title{
54. C1-C8 HYDROCARBONS IN SEDIMENTS FROM THE LOWER CONTINENTAL RISE, DEEP SEA DRILLING PROJECT SITE 603 ${ }^{1}$
}

\author{
Jean K. Whelan and Christine Burton, Woods Hole Oceanographic Institution²
}

\begin{abstract}
Small amounts of $\mathrm{C} 1-\mathrm{C} 8$ hydrocarbons were detected in continental rise sediments from DSDP Site 603. Organiccarbon-lean sections contained only $\mathrm{Cl}-\mathrm{C} 3$ compounds believed to have migrated from organic-carbon-rich sections. Heavier (C4-C8) hydrocarbons were found only in organic-carbon-rich sections. Restricted and sporadic distribution of C4-C6 compounds in $0-1100 \mathrm{~m}$ sub-bottom sediments suggest low-temperature $\left(<20^{\circ} \mathrm{C}\right)$ biological/chemical generation processes. Increased $\mathrm{C} 4-\mathrm{C} 8$ concentrations and complexity, including unusually high levels of xylene, were detected in two deeper Cretaceous sections $(603-34-2,134 \mathrm{~cm}$ and $603-81-3,120 \mathrm{~cm})$. This behavior, which was not observed in 17 other samples from sub-bottom depths greater than $1100 \mathrm{~m}$, is similar to that observed in immature surface sediments from the geothermally active Guaymas Basin (Gulf of California) area.
\end{abstract}

\section{INTRODUCTION}

Small amounts [parts per billion (ppb)] of light hydrocarbons have been detected in surface and DSDP sediments from many areas. In immature fine-grained sediments, traces of these compounds are produced in situ by a combination of low-temperature $\left(<30^{\circ} \mathrm{C}\right)$ chemical and biological processes, which could occur near the sediment/water interface before burial (Whelan, 1984; Whelan and Hunt, 1983). Migration of these hydrocarbons larger than propane (C3) is minimal, being on the order of centimeters, between Cretaceous interbedded green and black shale layers recovered from the South Atlantic, DSDP Leg 75 (Jasper et al., 1984; Whelan et al., 1985).

Leg 93 sediments provide an opportunity to further examine small-scale migration of these light hydrocarbons between interbedded organic-carbon-rich and -lean sediments. In addition, examination of several closely spaced samples from various depths may allow us to differentiate migration from thermal generation processes in the $25-35^{\circ} \mathrm{C}$ temperature range. Earlier work shows that in this temperature range, light hydrocarbons begin to increase in both amount and complexity above levels in surface sediments (Whelan and Hunt, 1983).

\section{EXPERIMENTAL}

The methods used in this work have been described in detail elsewhere (Whelan, 1984). Briefly, frozen sediment is placed in a stainless steel vessel equipped with a septum. After distilled water and helium are added, the vessel is sealed, shaken, and heated at $90^{\circ} \mathrm{C}$ for $30 \mathrm{~min}$. to drive volatile compounds into the gas phase. The compounds released are analyzed by gas chromatography and peak areas are measured using an electronic integrator.

\section{RESULTS AND DISCUSSION}

Except for samples at 160 and $1130 \mathrm{~m}$ sub-bottom, the amounts of sorbed methane in Holes 603B and 603C

\footnotetext{
${ }^{1}$ van Hinte, J. E., Wise, S. W., Jr., et al., Init. Repts. DSDP, 93: Washington (U.S. Govt, Printing Office).

2 Address: Chemistry Department, Woods Hole Oceanographic Institution, Woods Hole, MA 02543 .
}

1983). (Throughout the remainder of this chapter, the term "biological" will also include any chemical processes occurring at temperatures of less than $20^{\circ} \mathrm{C}$; these probably occur together with and are not distinguishare generally low (Fig. 1). Amounts of C1-C5 hydrocarbons from 0 to $1600 \mathrm{~m}$ sub-bottom are shown in Table 1 and Figure 1 and, on an expanded scale, Figure 2. Methane gas pockets were found throughout these holes, particularly in Hole 603B. The methane measurements represent residual gas remaining in these cores after freezing, sectioning, and storage. Thus, methane concentrations in Table 1 are qualitative only. However, based on previous work with surface sediments (Whelan, 1984; Whelan and Hunt, 1983; Whelan et al., 1985, and references cited therein), the amounts of sorbed methane retained by anoxic sediments are generally higher than for more oxic sediments not exposed to significant methanogenic activity.

Figure 2 shows a magnification of the $\mathrm{C} 1-\mathrm{C} 3$ compounds where the methane is generally accompanied by traces of ethane and propane that appear to be covariant with methane. (The magnification shows the covariance, which cannot be seen in Fig. 1). This behavior is typical of many immature, gassy DSDP sediments. These small amounts of ethane and propane are probably microbiologically produced near the sediment/water interface (Oremland, 1981). In deeper horizons, below $900 \mathrm{~m}$, they may be produced by low-temperature thermal processes (Rice and Claypool, 1981). However, no general increase of C2 and C3 with depth is observed at Site 603 (Fig. 2), as should be seen if production were occurring via a thermal maturation process (Rice and Claypool, 1981).

A few sections of these holes showed traces of C6-C8 compounds (Table 2). In the shallower sections to 1100 $\mathrm{m}$, the $\mathrm{C} 6$ and $\mathrm{C} 8$ constituents are of limited compound distribution (consisting of $n$-hexane and $n$-heptane only at $969 \mathrm{~m}$ sub-bottom), suggesting that these compounds were produced by biological/low-temperature chemical processes in shallower sections, as occurs, for example, in surface cores from the Peru Shelf (Whelan and Hunt, 
ng hydrocarbon/g dry wt. sediment (ppb)

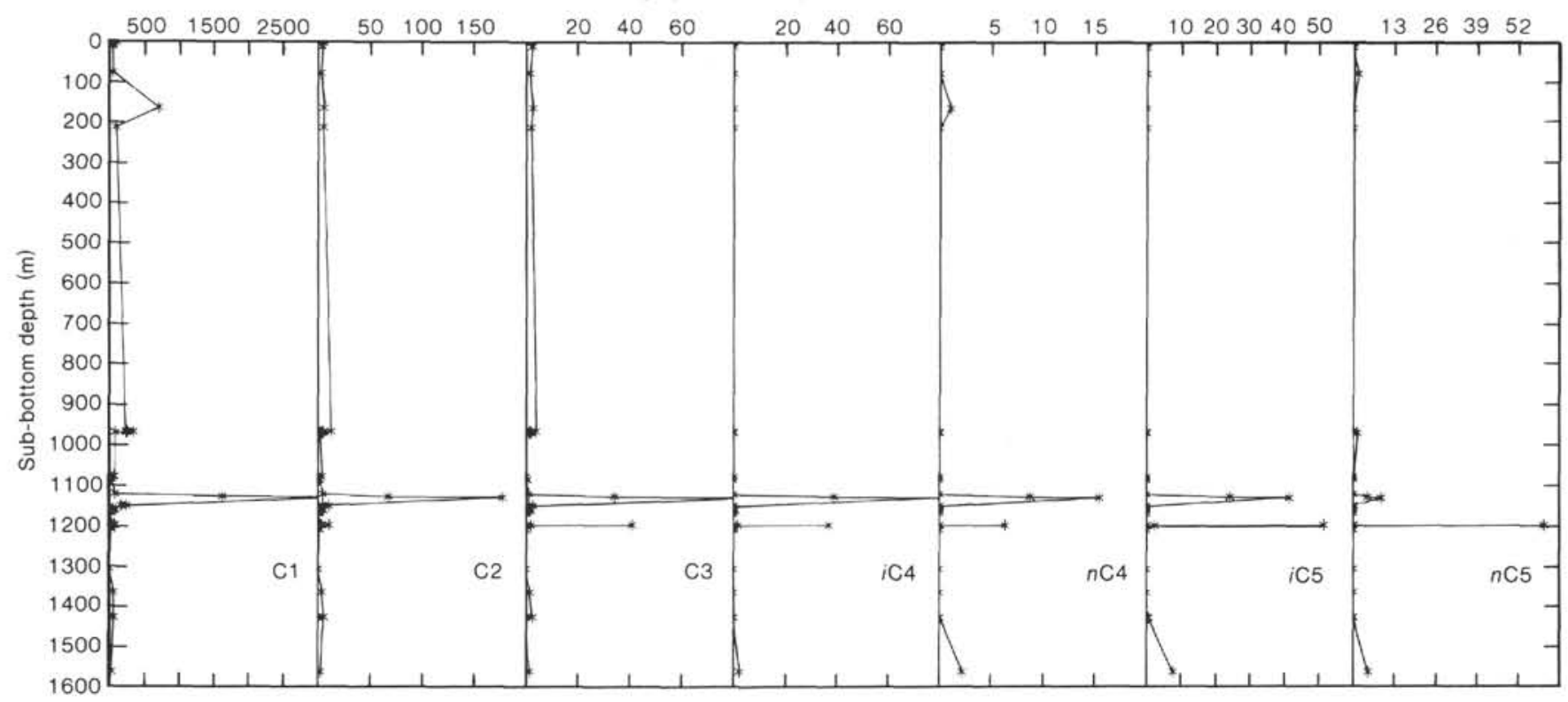

Figure 1. C1-C5 alkanes sorbed on Site 603 sediments. Abbreviations: methane (Cl); ethane (C2); propane (C3); isobutane (iC4); $n$-butane $(n \mathrm{C} 4)$; isopentane ( $i$ C5); $n$-pentane ( $n$ C5).

Table 1. Concentrations of C1-C5 alkanes at DSDP Site 603.

\begin{tabular}{|c|c|c|c|c|c|c|c|c|}
\hline \multirow{2}{*}{$\begin{array}{c}\text { Sample } \\
\text { (interval in } \mathrm{cm} \text { ) }\end{array}$} & \multirow{2}{*}{$\begin{array}{c}\text { Sub-bottom } \\
\text { depth (m) }\end{array}$} & \multirow[b]{2}{*}{ Description } & \multirow[b]{2}{*}{$\mathrm{C}_{\text {org }}(\%)$} & \multicolumn{5}{|c|}{ ng $\mathrm{HC} / \mathrm{g}$ dry wt. sediment } \\
\hline & & & & $\mathrm{Cl}$ & $\mathrm{C} 2$ & $\mathrm{C} 3$ & $\mathrm{C} 4$ & C5 \\
\hline \multicolumn{9}{|l|}{ Hole $603 \mathrm{C}$} \\
\hline $10-1,50$ & 77.8 & Silty clay olive-green & nd & 46 & 3 & 1.6 & 0 & 1.4 \\
\hline $20-1,50$ & 164.9 & Silty-siderite & nd & 708 & 6.1 & 2.8 & 1.1 & 0 \\
\hline $25-1,50$ & 212.9 & Silty clay olive green & nd & 95 & 5.5 & 2.0 & 0 & 0 \\
\hline \multicolumn{9}{|l|}{ Hole 603B } \\
\hline $16-1,14$ & 965.5 & Red/beige & $<0.1$ & 245 & 13 & 3.9 & 0 & 0 \\
\hline $16-1,127$ & 966.7 & Brown and red/beige & $<0.1$ & 266 & 5.6 & 2 & 0 & 0 \\
\hline $16-2,27$ & 967.2 & Dark gray & $<0.1$ & 351 & 5.0 & 1.5 & 0 & 0 \\
\hline $16-2,138$ & 968.3 & Dark gray & $<0.1$ & 247 & 4.4 & 1.3 & 0 & 0 \\
\hline $16-3,63$ & 969.0 & Red/beige & $<0.1$ & 91 & 2.3 & 0 & 0 & 0 \\
\hline $28-4,35$ & 1078 & Dark gray-ciay/silt & $<0.1$ & 17 & 0 & 0 & 0 & 0 \\
\hline $29-3,120$ & 1085 & Dark red-clay/silt & $<0.1$ & 37 & 2.2 & 0.6 & 0 & 0 \\
\hline $33-2,117$ & 1121.2 & Green quartz/mica & 4 & 87 & 5 & 1.2 & 0 & 0 \\
\hline $34-1,53$ & 1128 & Dark gray carbonaceous/clay & 10.5 & 1630 & 68 & 34 & 48 & 29 \\
\hline $34-2,134$ & 1130.34 & Dark gray carbonaceous/clay & 13.6 & 3410 & 178 & 85 & 98 & 50 \\
\hline $36-3,122$ & 1149.72 & Dark gray carbonaceous/clay & 1 & 245 & 4.8 & 1.2 & 0 & 0 \\
\hline $36-3,125$ & 1149.75 & Dark gray carbonaceous/clay & 1 & 171 & 11 & 2.7 & 0 & 0 \\
\hline $37-4,120$ & 1160.2 & Dark gray/green & 0.3 & 55 & 3.7 & 1.2 & 0 & 0 \\
\hline $37-4,124$ & 1160.24 & Org-rich clay/pyr & 1.1 & 47 & 1.8 & 1.6 & 0.8 & 0 \\
\hline $37-4,126$ & 1160.26 & Dark gray green clay & 0.3 & 93 & 5.3 & 1.8 & 0 & 0 \\
\hline $38-3,125$ & 1167.75 & Bioturb. clay & $<0.1$ & 18 & 1.0 & 0 & 0 & 0 \\
\hline $42-1,65$ & 1197.85 & Layers-green and gray & $0.7-1.2$ & 40 & 2 & 0 & 0 & 0 \\
\hline $42-1,73$ & 1197.93 & Dark gray & 2.5 & 80 & 11 & 41 & 43 & 112 \\
\hline $42-1,80$ & 1198 & Layers-green and gray & $0.7-1.2$ & 76 & 4 & 1.8 & 1.5 & 2.5 \\
\hline $43-4,4$ & 1209.3 & Red brown & $<0.1$ & 25 & 1.8 & 0 & 0 & 0 \\
\hline $53-4,119$ & 1306.5 & Dark gray-nanno clay & 0.2 & 10 & 0.7 & 0 & 0 & 0 \\
\hline $59-4,120$ & 1364.4 & Grn gray sandstone & 0.6 & 62 & 4.1 & 1.6 & 0 & 0 \\
\hline $66-2,120$ & 1426.5 & White light gray & $<0.1$ & 63 & 5.6 & 2.5 & 0 & 0 \\
\hline $66-2,128$ & 1426.6 & Green to dark gray & nd & 7 & 0 & 0 & 0 & 0 \\
\hline $66-2,147$ & 1426.8 & Light gray & $<0.1$ & 58 & 5.4 & 0 & 0 & 0 \\
\hline $81-3,120$ & 1562.4 & Gray & 0.4 & 30 & 2.8 & 1.5 & 4.6 & 13 \\
\hline
\end{tabular}

1983). (Throughout the remainder of this chapter, the term "biological" will also include any chemical processes occurring at temperatures of less than $20^{\circ} \mathrm{C}$; these probably occur together with and are not distinguishable from strictly biological processes, as discussed in detail in Whelan, 1984, and Whelan and Hunt, 1983.) In contrast, a much larger diversity of compounds is commonly observed in sediments below $1100 \mathrm{~m}$ sub-bottom, suggesting a thermal origin. The geothermal gradient at thịs site is $2.19^{\circ} \mathrm{C}$ per $100 \mathrm{~m}$. If it is assumed that 


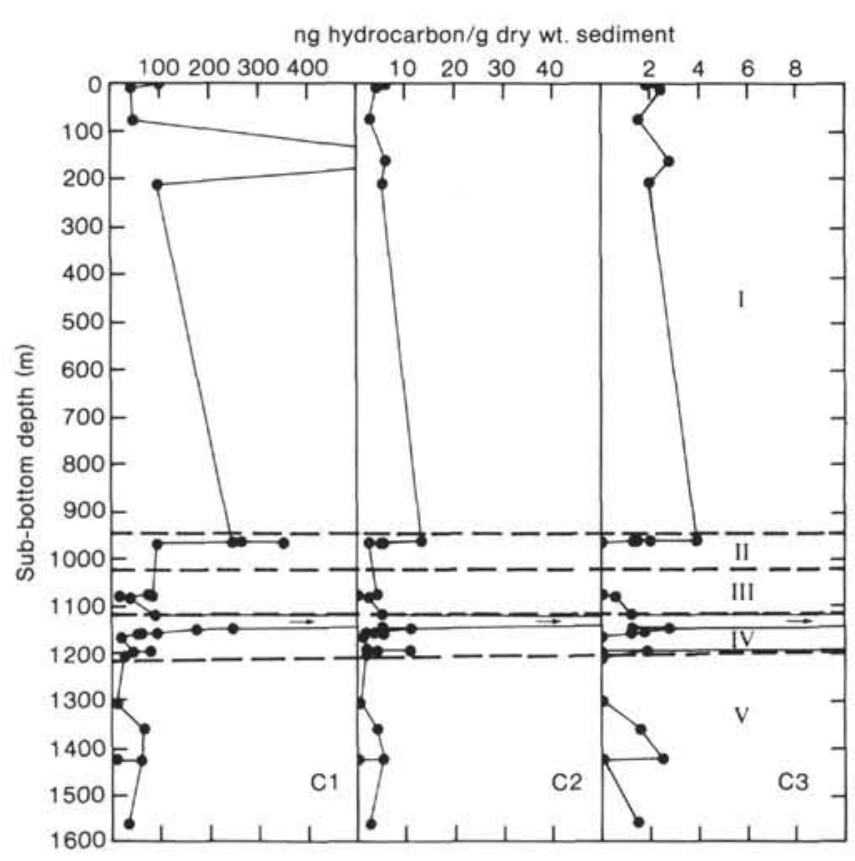

Figure 2. Expansion of C1-C3 hydrocarbon profiles. Dashed lines show unit boundaries: I is Pleistocene to Eocene claystone; II is Eocene claystone; III is lower Paleogene variegated claystone; IV is Cretaceous claystone (including black shales); $\mathrm{V}$ is Cretaceous laminated marl and bioturbated limestone.

bottom waters average $4^{\circ} \mathrm{C}$, then current geothermal temperatures would be about $30^{\circ} \mathrm{C}$ at $1150 \mathrm{~m}$ sub-bottom. The sediments show no evidence from sedimentological or pyrolysis data (Meyers et al., this volume) of exposure to higher temperatures in the past. Thus, any thermal processes operating at this site must occur at low temperatures (as compared to about $50^{\circ} \mathrm{C}$, the minimum generally accepted as representing the start of the oilgeneration window; Hunt, 1979, p. 101).

The $\mathrm{C} 1$ to $\mathrm{C} 8$ profiles of specific intervals (Tables 1 and 2 ) are presented here with a discussion of possible sources for the compounds.

\section{Surface (78-213 m sub-bottom) (Pleistocene)}

$\mathrm{C} 1$ and $\mathrm{C} 3$ hydrocarbons were detected in five sections with methane levels 10 to 100 times greater than those of ethane and propane. This is typical of sorbed hydrocarbons in anoxic sediments that have been affected by methanogenic bacteria (Whelan, 1984; Whelan and Hunt, 1983). The absence of any C6-C8 compounds and only restricted occurrences of $n-\mathrm{C} 4$ and $n-\mathrm{C} 5$ support a biogenic rather than a thermogenic source for these compounds. This limited compound distribution is typical of sediments subjected only to biological processes and not exposed to thermal hydrocarbon generation or to migrated or anthropogenic hydrocarbons. The current geothermal temperature at the bottom of this sequence ( $213 \mathrm{~m}$ sub-bottom) can be calculated to be about $8^{\circ} \mathrm{C}$, which is consistent with the absence of hydrocarbons typical of thermal generation. Pore water sulfate levels drop to values below $2 \mathrm{mM}$ by $17 \mathrm{~m}$ sub-bottom so that microbiological methane production is geochemically possible in all deeper sediments below this depth, assuming other nutrients are adequate (Rice and Claypool, 1981).
Methane is about an order of magnitude higher at $165 \mathrm{~m}$ sub-bottom than in sediments above and belowat 78 and $213 \mathrm{~m}$ sub-bottom. These data suggest that the sediment at $165 \mathrm{~m}$ sub-bottom (603C-20-1, 50-54 cm) may have been subjected to greater influence of methanogens than adjacent sections.

Samples 603B-16-1, 14-16 cm to 603B-16-3, 63-65 cm (965.5-969.0 m sub-bottom) (Eocene)

These radiolarian claystones show large color variations not related to their organic carbon content $(<0.1 \%)$. Organic carbon is too low for significant light hydrocarbon production from thermogenic or biogenic sources. Thus, the small amounts of methane, ethane, and propane in the five sections examined are probably migrated, a conclusion supported by comparable levels of these compounds in all sections. Compounds larger than $\mathrm{C} 3$ are not present. This observation is consistent with previous work on alternating green and black shale (organic-lean and -rich) layers from Cretaceous shales from the South Atlantic (DSDP Leg 75), where it was concluded that only $\mathrm{C} 1$ and $\mathrm{C} 2$ appeared to be consistently migrating from organic-rich into adjacent organic-lean sections (Jasper et al., 1984; Whelan et al., 1985). In the current work, propane also appears to have undergone some migration throughout the section.

\section{Samples 603B-28-4, 35-36 cm and 603B-29-3, 120-124 cm (1078 and $1985 \mathrm{~m}$ sub-bottom, respectively) (Paleogene)}

Both of these samples are terrigenous silty claystones containing less than $0.1 \%$ organic carbon. Only traces of methane occur in the shallower sample, and only $\mathrm{C} 1-\mathrm{C} 3$ were detected in the deeper. No higher molecular weight compounds (C4-C8) were found. Methane is approximately 10 times less than in the $965-969 \mathrm{~m}$ subbottom section described previously.

\section{Samples 603B-33-2, 117-121 cm to 603B-36-3, 125-126 cm (1121.1-1149.75 m sub-bottom) (Cretaceous-Cenomanian-Turonian)}

Five samples from this section varied in color from gray to dark gray with moderate to very high $(1-13.6 \%)$ organic carbon content. Maximum organic carbon and light hydrocarbon values occur in two samples near the center of the section. Variations in $\mathrm{C} 1-\mathrm{C} 5$ hydrocarbons between organic-carbon-rich and -lean sections are still apparent when the data are normalized to organic carbon (Table 3), although the differences have been reduced somewhat. No C4-C8 compounds were detected in Samples $306 \mathrm{~B}-33-2,117 \mathrm{~cm}(6.8 \mathrm{~m}$ sub-bottom, above the richer intervals) or in $306 \mathrm{~B}-36-3,122 \mathrm{~cm}$ or $306 \mathrm{~B}-36-3$, $125 \mathrm{~cm}$ ( $19.4 \mathrm{~m}$ sub-bottom, below the rich intervals). Thus, vertical migration of the $\mathrm{C} 4+$ compounds from rich to lean sections has not occurred over distances of a few meters, consistent with results found previously over much shorter vertical distances at other sites.

The three leaner sections contain moderate amounts of organic carbon (1-4\%), which also might be capable of undergoing in situ light hydrocarbon generation. However, only $\mathrm{C} 1-\mathrm{C} 3$ compounds are found in these intervals in levels comparable to those in the more organic- 
Table 2. Content of C6-C8 hydrocarbons at DSDP Site 603.

\begin{tabular}{|c|c|c|c|c|c|c|c|c|c|c|}
\hline \multirow[b]{2}{*}{ Compounds } & \multicolumn{10}{|c|}{ Sample depths (m) } \\
\hline & 77.8 & 969 & 1128 & 1130 & 1160 & 1197.93 & 1198.0 & 1306.5 & 1426.6 & 1562 \\
\hline \multicolumn{11}{|l|}{ Alkanes } \\
\hline Sum C6 & 0 & 1.6 & 19 & 27 & 0.65 & 44 & 6.9 & 4.4 & 4.0 & 17 \\
\hline Sum C7 & 0 & 2.4 & 8.9 & 12 & 0 & 3.6 & 0 & 9.3 & 1.5 & 17.7 \\
\hline Sum C8 & 0 & 0 & 2.8 & 5.2 & 0 & 1.8 & 0 & 8.4 & 0 & 3.1 \\
\hline \multicolumn{11}{|l|}{ Aromatics } \\
\hline Tol and benz & 0 & 0 & 0 & 0 & 0 & 5.8 & 0 & 6.8 & 0 & 0 \\
\hline Xylenes & 0 & 0 & 0 & 0 & 0 & 110 & 0 & 0 & 0 & 12 \\
\hline \multicolumn{11}{|c|}{ Individual compounds ${ }^{\mathrm{a}}$} \\
\hline $\mathrm{CP}$ & 0.83 & 0 & 0.39 & 1.2 & 0 & 21 & 0 & 0 & 0 & 0 \\
\hline 23DMB & 0 & 0 & 1.1 & 1.6 & 0 & 0.81 & 0 & 0.49 & 0 & 0.88 \\
\hline 2MP & 0 & 0 & 8.5 & 11.2 & 0.65 & 37 & 6.93 & 1 & 1.5 & 4.3 \\
\hline $3 \mathrm{MP}$ & 0 & 0 & 1.1 & 1.5 & 0 & 1.1 & 0 & 0 & 0 & 1.1 \\
\hline$n \mathrm{C} 6$ & 0 & 1.6 & 1.1 & 1.2 & 0 & 2.2 & 0 & 0 & 0 & 2.2 \\
\hline MPC & 0 & 0 & 5.9 & 9.7 & 0 & 1.6 & 0 & 2.9 & 2.5 & 6.21 \\
\hline $\mathrm{CH}$ & 0 & 0 & 1.6 & 2.1 & 0 & 1.3 & 0 & 0 & 0 & 2 \\
\hline $2 \mathrm{MH}$ & 0 & 0 & 0.56 & 0 & 0 & 1.1 & 0 & 0 & 0 & 1.1 \\
\hline 22DMP & 0 & 0 & 0 & 0 & 0 & 0.53 & 0 & 0 & 0 & 0 \\
\hline 24DMP & 0 & 0 & 0.56 & 0 & 0 & 0 & 0 & 0 & 0 & 0 \\
\hline 1T3DMCP & 0 & 0 & 2.1 & 3.6 & 0 & 0 & 0 & 1.3 & 0 & 2.5 \\
\hline 1T2DMCP & 0 & 0 & 0.85 & 1.4 & 0 & 0 & 0 & 4.3 & 0 & 4.2 \\
\hline 1C2DMCP & 0 & 0 & 0.98 & 1.7 & 0 & 0 & 0 & 0.94 & 0 & 0.9 \\
\hline$n \mathrm{C} 7$ & 0 & 2.43 & 0.66 & 0 & 0 & 1.4 & 0 & 0 & 0 & 2.4 \\
\hline 3EP & 0 & 0 & 2.2 & 3.8 & 0 & 0 & 0 & 0 & 0 & 2.1 \\
\hline $\mathrm{MCH}$ & 0 & 0 & 0.98 & 1.6 & 0 & 0.64 & 0 & 2.8 & 1.5 & 4.5 \\
\hline BENZ & 0 & 0 & 0 & 0 & 0 & 1.4 & 0 & 0 & 0 & 0 \\
\hline TOL & 0 & 0 & 0 & 0 & 0 & 4.3 & 0 & 6.8 & 0 & 0 \\
\hline 234TMP & 0 & 0 & 2.0 & 0 & 0 & 0 & 0 & 3.9 & 0 & 0 \\
\hline $\mathrm{DMH}^{\mathrm{b}}$ & 0 & 0 & 0.71 & 1.5 & 0 & 1.8 & 0 & 0 & 0 & 2.0 \\
\hline$n \mathrm{C} 8$ & 0 & 0 & 0 & 3.7 & 0 & 0 & 0 & 0 & 0 & 0 \\
\hline 1С2Т3ТMCP & 0 & 0 & 0 & 0 & 0 & 0 & 0 & 2.1 & 0 & 1.1 \\
\hline 1T2DMCH & 0 & 0 & 0 & 0 & 0 & 0 & 0 & 2.3 & 0 & 0 \\
\hline ETBENZ & 0 & 0 & 0 & 0 & 0 & 48 & 0 & 0 & 0 & 7.3 \\
\hline m\&p XYL & 0 & 0 & 0 & 0 & 0 & 44 & 0 & 0 & 0 & 4.9 \\
\hline oXYL & 0 & 0 & 0 & 0 & 0 & 18 & 0 & 0 & 0 & 0 \\
\hline
\end{tabular}

${ }^{a}$ Abbreviations: cyclopentane (CP); 2,3-dimethylbutane (23DMB); 2-methylpentane (2MP); 3-methylpentane (3MP); $n$-hexane ( $n \mathrm{C} 6)$; methylcyclopentane (MCP); cyclohexane (CH); 2-methylhexane (2MH); 2,2-dimethylpentane (22DMP); 2,4-dimethylpentane (24DMP); 1-trans-3-, 1-trans-2-, and 1-cis-2-dimethylcyclopentane (1T3DMCP, 1T2DMCP, and 1C2DMCP, respectively); $n$-heptane ( $n \mathrm{C} 7)$; 3-ethylpentane (3EP); methylcyclohexane (MCH); benzene (BENZ); toluene (TOL); 2,3,4-trimethylpentane (234TMP); dimethylhexane (DMH); $n$-octane ( $n$ C8); 1-cis-2-trans-3-trimethylcyclopentane (1C2T3TMCP); 1-trans-2-dimethylcyclohexane (1T2DMCH); ethylbenzene (ETBENZ); $m$ - and p-xylene (m\&p XYL); o-xylene (o XYL).

${ }^{b}$ Total for all isomers.

Table 3. $\mathrm{C} 1-\mathrm{C} 5$ hydrocarbons-normalization to organic carbon.

\begin{tabular}{lcccccc}
\hline & & \multicolumn{5}{c}{$\mathrm{ng} \mathrm{HC} / \mathrm{g} \mathrm{C}_{\text {org }}$} \\
\cline { 3 - 7 } $\begin{array}{c}\text { Sample } \\
\text { (interval in cm) }\end{array}$ & $\mathrm{C}_{\text {org }}(\%)$ & Methane & Ethane & Propane & $n$-C4 & $n$-C5 \\
\hline $33-2,117$ & 4 & 21.8 & 1.2 & 0.3 & 0.0 & 0.0 \\
$34-1,53$ & 10.5 & 155.0 & 6.5 & 3.2 & 4.6 & 2.8 \\
$34-2,134$ & 13.6 & 224.2 & 13.1 & 6.2 & 7.2 & 3.7 \\
$36-3,122$ & 1 & 245.0 & 4.8 & 1.2 & 0.0 & 0.0 \\
$36-3,125$ & 1 & 171.0 & 10.7 & 2.7 & 0.0 & 0.0 \\
\hline
\end{tabular}

lean interval from 965-969 m sub-bottom, discussed previously. Thus, it seems probable that if in situ light hydrocarbon generation did take place in these samples, it was limited to the $\mathrm{C} 1-\mathrm{C} 3$ range.

Samples 603B-37-4, 120-122 cm to 603B-38-3, 125-132 cm (1160.2-1167.75 m sub-bottom) (Cretaceous-Albian-Cenomanian)

Of the four claystones examined, three contain less than $0.3 \%$ organic carbon. The $\mathrm{C} 1-\mathrm{C} 3$ compounds in the section may represent migrated compounds, as discussed previously for other organic-carbon-lean sections. Sample 37-4, 124-125 cm contains more organic carbon content $(1.1 \%)$ and pyrite lenses. However, levels of $\mathrm{C} 1-$ $\mathrm{C} 3$ are similar to the other three samples, suggesting migration and equilibration of these three low-molecularweight compounds throughout this section. The richer sample contains $0.8 \mathrm{ng} / \mathrm{g}$ of isobutane, $0.6 \mathrm{ng} / \mathrm{g}$ of 2 -methyl pentane, and no other $\mathrm{C} 4+$ compounds. The restricted distribution suggests that these compounds were biologically produced. The absence of these two compounds only $2-4 \mathrm{~cm}$ above and below shows that $\mathrm{C} 4$ and C6 compounds have not migrated vertically out of the organic-carbon-rich section.

Samples 603B-42-1, 65-67 cm to $603 \mathrm{~B}-43-4,0-4 \mathrm{~cm}$ (1197.85-1209.3 m sub-bottom)

(Cretaceous-Aptian-Albian)

Four samples were examined-three gray to dark gray layers are within $20 \mathrm{~cm}$ of each other, whereas the fourth 
red brown layer is $11.3 \mathrm{~m}$ sub-bottom deeper. The gray layers all contain 0.7 to $1.2 \%$ organic carbon with the center layer containing the highest amount. Levels of $\mathrm{C} 1$ and $\mathrm{C} 2$ in all of these are about equal, with the methane being about the same as in the $1160 \mathrm{~m}$ sub-bottom section and considerably lower than in some other organiccarbon-rich intervals (Table 1). These data are consistent with diffusion of $\mathrm{C} 1$ and $\mathrm{C} 2$ throughout the section. This interpretation is supported by approximately equal levels of $\mathrm{C} 1$ and $\mathrm{C} 2$ in the organic-carbon-lean $(<0.1 \%$ organic carbon) section at $1209 \mathrm{~m}$ sub-bottom.

The center two sections of this interval (603B-42-1, $73 \mathrm{~cm}$ and 603B-42-1, $80 \mathrm{~cm}$, Tables 1 and 2) contain $\mathrm{C} 3+$ compounds. The 603B- $42-1,80 \mathrm{~cm}$ sample shows a restricted hydrocarbon distribution consisting of a homologous series of isoalkanes-isobutane, isopentane, and isohexane (2MP in Tables 1 and 2). The limited distribution suggests the same biogenic source as for Sample $603 \mathrm{~B}-37-4,124-125 \mathrm{~cm}$ at $1160.24 \mathrm{~m}$, which contains an almost identical distribution. The possibility that these compounds have diffused in from the richer interval $7 \mathrm{~cm}$ above $(603 \mathrm{~B}-42-1,73-75 \mathrm{~cm})$ is unlikely because the shallower interval contains slightly more $n$-pentane than $i$-pentane, whereas the deeper interval contains only $i$-pentane. The diffusion coefficient of iso-C5 is a little higher than for $n$-pentane (Sahores and Witherspoon, 1970), but not enough to account for such a large fractionation over these short distances. Thus, it is concluded that the C5 + fraction (which is fairly complex in Sample $603 \mathrm{~B}-41-1,73-75 \mathrm{~cm}$ ) is not migrating significantly in these sediments, even over distances as small as $7 \mathrm{~cm}$.

Because of the apparent nondiffusion of C5-C8 hydrocarbons in this interval, it is proposed that the complex light hydrocarbon mixture in Sample 603B-42-1, $73-75 \mathrm{~cm}$ is either thermogenic in source or caused by some migration process other than diffusion. The presence of aromatic compounds, benzene, toluene, and relatively large amounts of xylene, suggest that this mixture was formed at a relatively high temperature, as found for the Guaymas Basin samples from the Gulf of California (Whelan and Hunt, 1982). Alternatively, migration of light hydrocarbons favors the more water soluble aromatic over the less soluble aliphatic hydrocarbons (Thompson, 1979). There is not evidence in the sedimentological record to suggest higher paleotemperatures for this interval (see site chapters, this volume). Thus, some sort of localized lateral migrational process is suggested, possibly similar to that found in surface organiccarbon-rich sediments from the Guaymas Basin (Whelan and Hunt, 1982). Such a process requires that adjacent sediments received a source of heat at some time in the past. Alternatively, petroleum hydrocarbons can migrate considerable distances (sometimes hundreds of miles) from petroleum sources or reservoirs through fault or fracture systems.

\section{Samples 603B-66-2, 120-123 cm to 603B-66-2, 147-150 cm (1426.5-1426.8 m sub-bottom) (Cretaceous-Hauterivian)}

These three samples contain less than $0.1 \%$ organic carbon and small amounts of $\mathrm{C} 1-\mathrm{C} 3$ hydrocarbons as- sumed to have migrated into this section. The amounts are comparable to those in other organic-carbon-lean intervals of this hole, as discussed previously.

\section{Sample 603B-81-3, 120-124 cm (1524.4 m sub-bottom) (Cretaceous-Valanginian)}

This sediment is a nannofossil claystone/limestone. Sediments $18 \mathrm{~cm}$ below this section contain a large wood chunk and wood fragments (see site chapters, this volume). Organic carbon is moderate to low $(0.4 \%)$. However, the section contains a complex series of C4-C8 hydrocarbons suggesting a thermogenic source. Benzene and toluene are absent but two xylene isomers are present. Thus, a nondiffusional (lateral) migrational process could be responsible, as suggested for Sample 603B-34-2, $134 \mathrm{~cm}$.

\section{CONCLUSIONS}

1. Organic-carbon-lean sections generally contain only $\mathrm{C} 1-\mathrm{C} 3$ hydrocarbons that are believed to have migrated throughout the hole from organic-carbon-rich sections. In richer sections, these compounds show sporadically higher values, particularly in shallower parts of the hole. The increased "smearing out" of the profiles with depth suggests that diffusion over geological time smooths out spikes, which are initially caused by early biogenic production near the sediment/water interface.

2. No evidence was found for vertical diffusional migration of C4-C8 hydrocarbons, even over a few $\mathrm{cm}$, in any section of the hole.

3. Sporadic and simple distributions of C4-C6 compounds in organic-carbon-rich, shallow sections suggest in situ generation by biological (or low-temperature chemical) processes occurring near the sediment/water interface shortly after deposition as commonly found for surface sediments (Whelan and Hunt, 1984).

4. The concentrations and complexity of the C4-C8 hydrocarbon mixture increased in two deeper sections (603B-34-2, $134 \mathrm{~cm}$ and 603B-81-3, $120 \mathrm{~cm}$ ), suggesting a switch either to thermal generation over a very narrow depth range (for which there is no sedimentological evidence) or to the influence of a nondiffusional (lateral) petroleum migration process, possibly similar to that found in immature surface sediments of the geothermally hot Guaymas Basin area. The relatively high proportions of xylene and ethyl benzene found in these two intervals are consistent both with a higher temperature source and/or with lateral petroleum migration.

\section{ACKNOWLEDGMENTS}

We would like to thank Dr. Ken Peters and Dr. Keith Thompson for their careful reading of the manuscript. This work was supported by Department of Energy Contract No. EG-77-02-4392. Woods Hole Oceanographic Institution Contribution No. 6051.

\section{REFERENCES}

Hunt, J. M., 1979. Petroleum Geochemistry and Geology: San Francisco (W. H. Freeman).

Jasper, J. P., Whelan, J. K., and Hunt, J. M., 1984. Migration of C1 to $\mathrm{C} 8$ volatile organic compounds in sediments from the Deep Sea Drilling Project, Leg 75, Hole 530A. In Hay, W. W., Sibuet, J. C., et al., Init. Repts. DSDP, 75, Pt. 2: Washington (U.S. Govt. Printing Office), 1001-1008. 
Oremland, R. S., 1981. Microbial formation of ethane in anoxic estuarine sediments. Appl. Environ. Microbiol., 42:122-129.

Rice, D. D., and Claypool, G. E., 1981. Generation, accumulation and resource potential of biogenic gas. Am. Assoc. Pet. Geol. Bull., 65:5-25.

Sahores, J. J., and Witherspoon, P. A., 1970. Diffusion of light hydrocarbons in water from $2^{\circ} \mathrm{C}$ to $80^{\circ} \mathrm{C}$. In Hobson, G. D., and Speers, G. C. (Eds.), Advances of Organic Geochemistry: New York (Pergamon Press), pp. 219-230.

Thompson, K. F. M., 1979. Light hydrocarbons in subsurface sediments. Geochim. Cosmochim. Acta, 43:657.

Whelan, J. K., 1984. Volatile C1-C8 compounds in marine sediments. In Odham, G., Larsson, L., and Mardh, P. (Eds.), Gas Chromatography/Mass Spectrometry Applications in Microbiology: New York (Plenum Press),
Whelan, J. K., and Hunt, J. M., 1982. $\mathrm{C}_{1}-\mathrm{C}_{8}$ hydrocarbons in Leg 64 sediments, Gulf of California. In Curray, J. R., Moore, D. G., et al., Init. Repts. DSDP, 64, Pt. 2: Washington (U.S. Govt. Printing Office), 763-779.

1983. Volatile $\mathrm{Cl}-\mathrm{C} 8$ organic compounds in sediments from the Peru upwelling region. Org. Geochem., 5:13-28.

Whelan, J. K., Hunt, J. M., Jasper, J., and Huc, A., 1985. Migration of $\mathrm{Cl}-\mathrm{C} 8$ hydrocarbons in marine sediments. Org. Geochem., 6: 683-694.

Date of Initial Receipt: 29 March 1985

Date of Acceptance: 21 October 1985 